Jpn.J. Genet. (1984) 59, pp. 303-306

\title{
Enzyme activity and processivity of DNA relaxation in relation to salt concentrations in cauliflower DNA topoisomerase II
}

\author{
By Hideki Fukata and Hirosuke Fukasawa \\ Kobe Women's University, Suma-ku, Kobe 654
}

(Received April 28, 1984)

\begin{abstract}
The activity and the processivity in DNA relaxation of DNA topoisomerase II, isolated from cauliflower inflorescence, were examined with various ratios of $\mathrm{KCl}$ and $\mathrm{MgCl}_{2}$ concentrations in the reaction medium. The optimum concentrations for the relaxation were found to be $60 \mathrm{mM}$ for $\mathrm{KCl}$ and $5 \mathrm{mM}$ for $\mathrm{MgCl}_{2}$ in the same reaction mixture regarding the other elements. The reaction proceeds in a processive manner at low salt concentration, and in a distributive manner at high concentration, in which $\mathrm{MgCl}_{2}$ exhibits higher efficiency (five-fold) than $\mathrm{KCl}$.
\end{abstract}

DNA topoisomerases catalyze concerted breaking and rejoining of DNA backbone bonds, and remove superhelical turns in closed circular DNA (Wang and Liu 1979). In a previous article on the characterization of DNA topoisomerase isolated from cauliflower inflorescence, we reported that the optimum salt concentration for the type II enzyme activity was $50-100 \mathrm{mM}$ for $\mathrm{KCl}$

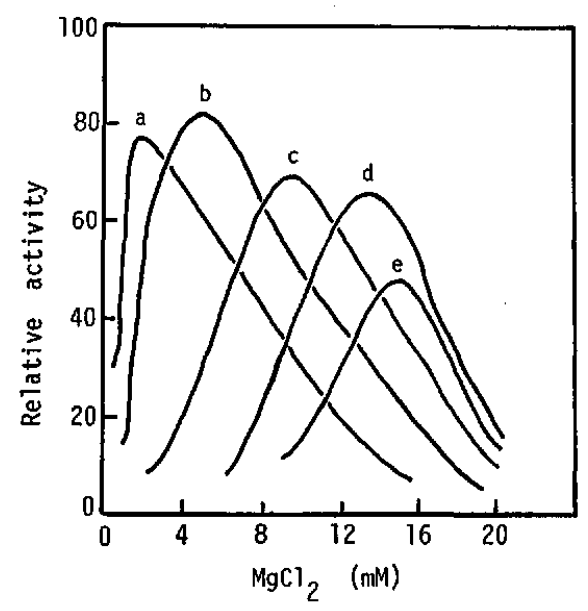

Fig. 1. Effect of $\mathrm{KCl}$ and $\mathrm{MgCl}_{2}$ concentrations on the activity of cauliflower DNA topoisomerase II. Superhelical pBR 322 DNA was treated with the enzyme for reaction in mixtures various in $\mathrm{KCl}$ and $\mathrm{MgCl}_{2}$ concentrations as shown, and relative activities were determined as the amounts of enzyme catalyzing to relax $0.5 \mu \mathrm{g}$ of superhelical DNA in $60 \mathrm{~min}$ at $35^{\circ} \mathrm{C}$ under the respective conditions. Absissa: $\mathrm{MgCl}_{2}$ concentration; Ordinate: relative activities at $\mathrm{KCl}$ concentration of ; (a) $80 \mathrm{mM}$, (b) $60 \mathrm{mM}$, (c) $40 \mathrm{mM}$, (d) $20 \mathrm{mM}$, (e) without $\mathrm{KCl}$. 


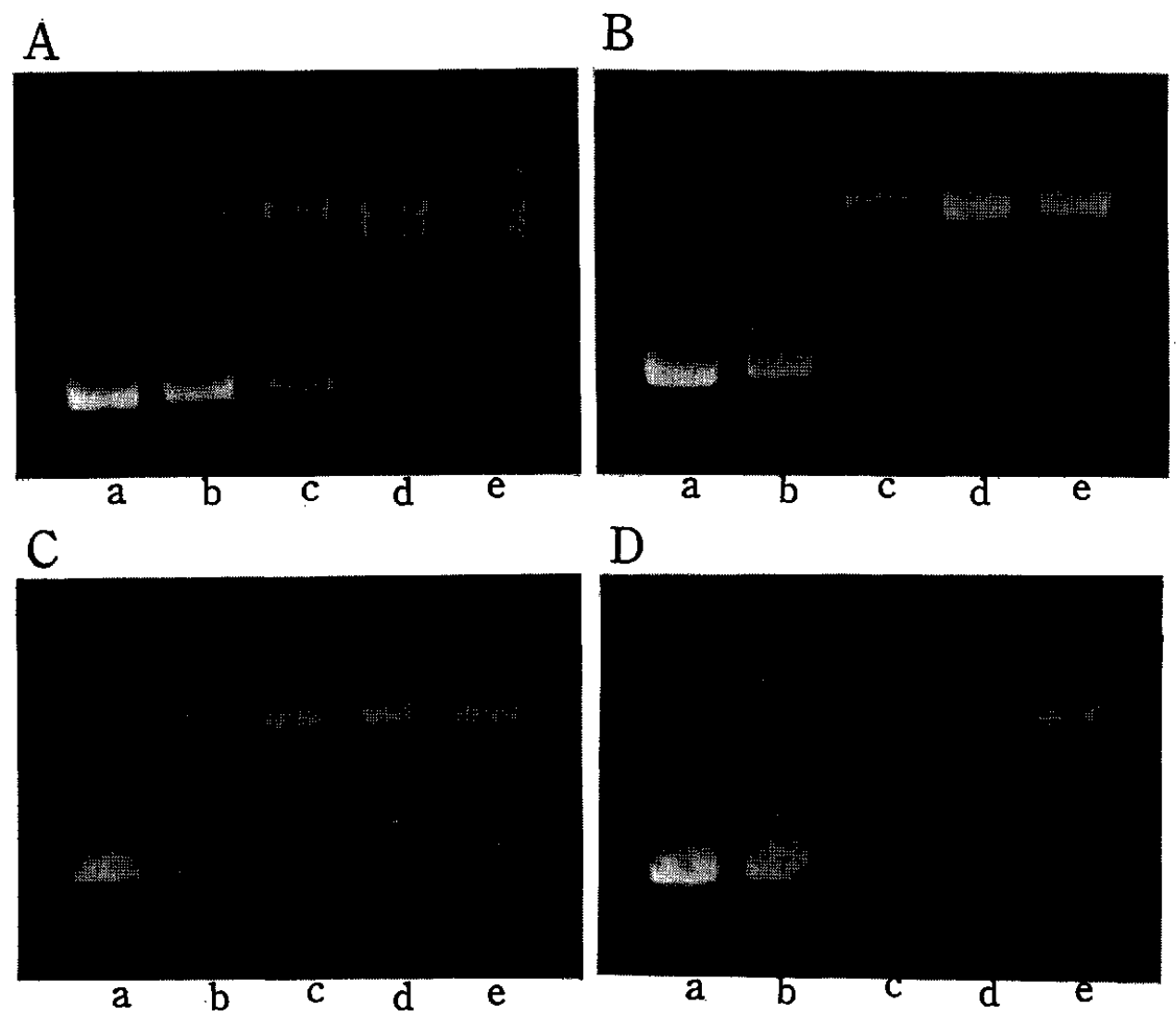

Fig. 2. Effect of $\mathrm{KCl}$ and $\mathrm{MgCl}_{2}$ concentrations on the processivity of cauliflower DNA topoisomerase II appeared in agarose gel electrophorograms of reaction products. Enzyme solution was diluted to make proper activity as indicated in Fig. 1. Reactions were performed in various reaction mixtures described in (A)-(D). Aliquots were removed at $0,15,30,45,60 \mathrm{~min}$, and analyzed in lanes a-e, respectively. (A) Reaction mixture containing $10 \mathrm{mM} \mathrm{MgCl} 2$ but without $\mathrm{KCl}$; resulting in processive manner. (B) Reaction mixture containing $20 \mathrm{~m} \mathrm{MgCl}_{2}$ and without $\mathrm{KCl}$; resulting in distributive manner. (C) Reaction mixture containing $60 \mathrm{mM} \mathrm{KCl}$ and $2 \mathrm{mM} \mathrm{MgCl}$; resulting in processive manner. (D) Reaction mixture containing $60 \mathrm{mM} \mathrm{KCl}$ and $10 \mathrm{mM} \mathrm{MgCl}_{2}$; resulting in distributive manner.

and $10 \mathrm{mM}$ for $\mathrm{MgCl}_{2}$ (Fukata and Fukasawa 1982). The present study was done to known more precise optimal concentrations for the activity of enzyme in relation to the processive and distributive modes of reaction. The procedure for DNA topoisomerase II preparation and the enzyme assay were the same as previously described (Fukata and Fukasawa 1983). The mode of reaction was analyzed by agarose gel electrophoresis of the reaction products. The standard reaction mixture was composed of $50 \mathrm{mM}$ Tris- $\mathrm{HCl}$ at $\mathrm{pH} 8.0$, $10 \mathrm{mM} \mathrm{MgCl}_{2}, .0 .5 \mathrm{mM}$ ATP, $1 \mathrm{mM}$ dithiothreitol, $160 \mu \mathrm{g} / \mathrm{ml}$ bovine serum albumin, $0.5 \mu \mathrm{g} \mathrm{pBR} 322 \mathrm{DNA}$ and $5 \mu \mathrm{l}$ enzyme solution. The optimum salt 


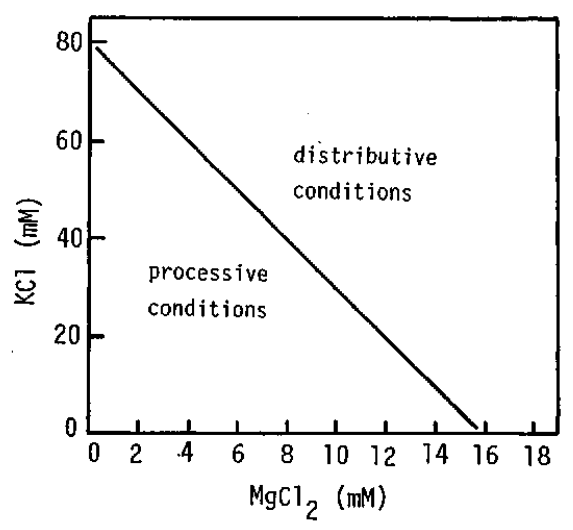

Fig. 3. Phase diagram for processivity of DNA relaxation by cauliflower DNA topoisomerase II. Processive or distributive modes of reactions were analyzed by agarose gel electrophoresis of reaction products under various ratios of $\mathrm{KCl}$ and $\mathrm{MgCl}_{2}$ concentrations in the same reaction mixture and various incubation times.

concentration for the DNA relaxation was determined examining various ratios of $\mathrm{KCl}$ (or $\mathrm{NaCl}$ ) and $\mathrm{MgCl}_{2}$ concentrations. As shown in Fig. 1, activity was the highest at when the concentration of $\mathrm{KCl}$ was $60 \mathrm{mM}$ and the one of $\mathrm{MgCl}_{2}$ was $5 \mathrm{mM}$ in the same reaction mixture. These optimum values were largely different from those for Drosophila DNA topoisomerase II (Osheroff et al. 1983); which were $150 \mathrm{mM}$ and $8 \mathrm{mM}$ for $\mathrm{KCl}$ and $\mathrm{MgCl}_{2}$, respectively.

The mode of reaction, whether the relaxation proceeds in processive or distributive manner, was inspected in respective experiments varying in the ratio of $\mathrm{KCl}$ and $\mathrm{MgCl}_{2}$ concentrations, enzyme concentration and reaction times. Fig. 2 shows some examples of action of the enzyme with processive mechanism at low salt concentrations and with distributive mechnism at high concentrations. The results have been summerized in Fig. 3, showing that reaction manner changes not only by ionic strength but also by the kind of ion; $\mathrm{MgCl}_{2}$ is more efficient (five-fold) than $\mathrm{KCl}$ to induce distributive manner.

The presence of two modes in manner of relaxation by DNA topoisomerase has been described also in type I enzyme from another sources (Kung and Mang 1977; Pederini and Ciarrocchi 1983). McConaughy et al. (1981) reported in rat liver nicking-closing enzyme (DNA topoisomerase I) that increasing salt concentration decreases the binding of the enzyme to DNA molecules. They explained that low salt concentration, only a few molecules of DNA become completely relaxed because the enzyme action is processive while at high salt concentration enzyme molecules can move between substrate DNA molecules easily, so that small amount of enzyme is enough to remove number of superhelical turns resulting in distributive manner. The present experiment with the cauliflower enzyme showed also similar results, that is, 
relatively high salt concentration is found to promote an activity, and consequently making relaxation reaction distributive (Fig. 3). However, the optimum concentrations for reaction were largely different from Drosophila DNA topoisomerase II, in which the optimums were high in ionic strength $(\geqq 175 \mathrm{mM})$ and high magnesium concencration $(\geqq 15 \mathrm{mM})$ for distributive relaxation reaction. DNA relaxation by type I enzyme of cauliflower DNA topoisomerase proceeds almost in processive manner even under the conditions which exhibits a distributive mode in type II enzyme. The reason remains to be determined.

\section{REFERENCES}

Fukata, H. and Fukasawa, H. (1982) Isolation and partial characterization of two distinct DNA topoisomerase from cauliflower inflorescence. J. Biochem. 91, 1337-1342.

FuKata, H. and FuKasawa, H. (1983) Further investigation on the characterization of DNA topoisomerases isolated from cauliflower inflorescence. Jpn. J. Genet. 58, 425-432.

Kung, V. T. and WANG, J.C. (1977) Purification and characterization of an $\omega$ protein from Micrococcus luteus. J. Biol. Chem. 252, 5398-5402.

McConaughy, B. L., Yong, L. S. and Champoux, J. J. (1981) The effect of salt on the binding of the eucaryotic DNA nicking-closing enzyme to DNA and chromatin. Biochim. Biophys. Acta 655, 1-8.

Osheroff, N., Shelton, E. R. and BrutlaG, D. L. (1983) DNA topoisomerase II from Drosophila melanogaster. Relaxation of supercoiled DNA. J. Biol. Chem. 258, 9536-9543.

PEDRINI, A. M. and CiarRocchi, G. (1983) Inhibition of Micrococcus luteus DNA topoisomerase I by UV photoproducts. Proc. Natl. Acad. Sci. USA 80, 1781-1791.

WANG, J. C. and LIU. L. F. (1979) DNA topoisomerases: Enzymes that catalyze the concerted breaking and rejoining of DNA backbone bonds. Molecular Genetics, Part III. pp. 65-88. Academic Press, New York. 